Dhaka Univ. J. Biol. Sci. 23(1): 47-51, 2013 (January)

\title{
EFFECTS OF SODIUM CHLORIDE ON OVIPOSITION AND DEVELOPMENT OF BLOWFLY, LUCILIA CUPRINA, (WIEDMANN) (DIPTERA : CALLIPHORIDAE)
}

\author{
Murshida Begum*, Mahmudul Hasan, A.S.M. Saifullah ${ }^{1}$ And M.A. Howlader \\ Department of Zoology, University of Dhaka, Dhaka-1000, Bangladesh \\ Key words: Blowfly, Oviposition, Growth and development
}

\begin{abstract}
Effects of five different concentrations of sodium chloride (5 to $25 \%$ ) treated fish flesh was tested on oviposition, growth and developmental parameters of blowfly, Lucilia cuprina (Wiedemann). The salt worked as an oviposition deterrent in the female flies. The highest amount of eggs $(0.247 \pm 0.0464 \mathrm{~g})$ was oviposited on lowest salt concentration (5\%) and the minimum amount $(0.0003 \pm$ $0.0004 \mathrm{~g}$ ) of eggs was laid on the highest salt concentration (25\%). The eggs laid on 20 and $25 \%$ salt treated fishes were not hatched. The larval periods were significantly affected by 10 and $15 \%$ salt treated fish while the pupal periods were prolonged at $15 \%$ of salt treated fish $(\mathrm{p}<0.05)$. Average larval and pupal durations in control were $4.543 \pm 0.18$ and $4.833 \pm 0.753$ days, respectively, whereas at $15 \%$ salt average larval and pupal durations were $5.937 \pm 0.133$ and $5.5 \pm 0.548$ days, respectively. The average weight of the larvae and pupae were also reduced with the high concentrations of salt. Pupation rate also significantly reduced at higher concentrations of salt. These results suggest that application of $15 \%$ salt in raw fish can effectively protect sun-drying fish from blowfly infestation.
\end{abstract}

\section{Introduction}

The blowfly, Lucilia cuprina, is a major pest of sheep in Australia and is the major causative agent for myiasis. Its infestation in sheep cost the Australian wool industry about $\$ 160$ million per annum ${ }^{(1)}$. Lucilia cuprina is the major pest of sun-drying fish industries in the coastal area of Bangladesh. The three major fish drying yards of Cox's Bazar district are the Nazirertek, Naniachatta and Sonadia island. Over 240 thousand metric tons of marine fishes are sun-dried per year in Bangladesh for local consumption and export purposes ${ }^{(2)}$. Although a number of dipteran insects are known to damage sea fishes during the process of sun-drying, L. cuprina is regarded as the most destructive pest in fish drying industries of Bangladesh. To prevent losses from the fly infestation the fish dryers use different types of chemical insecticides which are unacceptable because

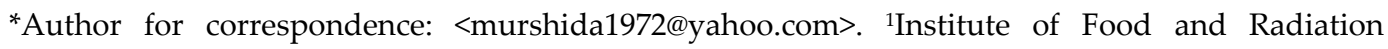
Biology, AERE, Savar, Dhaka, Bangladesh. 
they create certain problems to public health, livestock management, and environment ${ }^{(3)}$. This led pest management personnels towards the diversification of dry fish pest control strategy which are safe and relatively non-hazardous to public health and environment ${ }^{(4)}$. A considerable progress has been made in the use of radiation induced sterile insect technique (SIT) ${ }^{(4)}$. SIT is more feasible to control blowfly infestation, but more expensive and time consuming.

Application of sodium chloride $(\mathrm{NaCl})$ on raw fishes to control blowfly infestation is a traditional insect control method ${ }^{(2)}$. It is easy to apply and relatively less destructive to environment, human health and less expensive. The use of salt in certain concentration acts as oviposition deterrent and thus prevents the development of blowfly populations on dried fishes ${ }^{(5)}$. However, the fish driers of Bangladesh use this traditional control method without having enough knowledge about the critical amount of salt is required to prevent blowfly infestations. Indiscriminate use of salt often degrades the quality of the dried fishes and reduces acceptability in markets. Thus, the present study was undertaken to determine the effects of sodium chloride on the life cycle stages of the fly and to determine the doses required for preventing the blowfly infestation.

\section{Materials and Methods}

A stock colony of Lucilia cuprina was maintained in the laboratory of Radiation Entomology and Acarology Division of the Institute of Food and Radiation Biology, Atomic Energy Research Establishment, Savar, Dhaka. The laboratory temperature, humidity and photoperiods were $25 \pm 5^{\circ} \mathrm{C}, 70 \pm 10 \%$ and a $12 \mathrm{hrs}$ light : $12 \mathrm{hrs}$ dark, respectively. The adults were kept in fine meshed steel wire net covered cages of $20 \times 32$ $\times 30 \mathrm{~cm}$ and $48 \times 32 \times 20 \mathrm{~cm}$ sizes. The newly emerged flies were fed with bovine liver, solution of sugar and water soaked in cotton wad.

To determine the critical amount of salt required to act as an oviposition deterrent, different doses of salts were mixed with fixed amount of fish flesh to produce five different salt - flesh doses. Likewise 5, 10, 15, 20 and 25\% salt doses were prepared by mixing 1, 2, 3, 4 and $5 \mathrm{~g}$ of salt, respectively with $20 \mathrm{~g}$ amount of fish flesh separately. The salt treated fish fleshes in separate Petri dishes were placed in an adult rearing case containing two thousand adult flies of sexes. After 30 minutes, the dishes were removed from the cage and the cluster of eggs laid on the flesh were separated. The eggs from each dose were separately weighed by an electronic balance. The experiment was repeated for four times. The mean number of eggs laid in each tests were recorded.

The effect of salt on life cycle stages of the fly were studied in five tests. In the first test, $5 \%$ salt was mixed with $200 \mathrm{gm}$ of the fish flesh in Petri dishes. On the fish flesh, $0.05 \mathrm{gm}$ of eggs (1000 in number) were added and the dishes were placed in an adult rearing cage for observation of different variables of life cycle stages. The records were kept on the duration and weights of larval and pupal stages and the rates of pupation 
and adult emergence. The other four tests using 10,15, 20 and 25\% doses were similarly studied. The insects were observed at $24 \mathrm{hrs}$ intervals. Newly hatched larvae were fed on the fish flesh. The fully grown mature larvae were dropped into the sawdust contained in a plastic bowl for pupation. The larval duration was estimated on the basis of time taken from the hatching of the $1^{\text {st }}$ instar to the post feeding stage. The larval weight was recorded by weighing 25 post feeding larvae separately for each test. The pupation rate in each salt test also estimated. The pupal duration and pupal weights in each salt test were determined. The data were compared with those obtained in the control test. The emergence rate and the $\mathrm{F}_{1}$ adult longevity in each dose was also recorded. The mean of different variables were subjected to an ANOVA and a MRT(6).

\section{Results and Discussion}

The deterrent effects of different doses of sodium chloride on oviposition of $L$. cuprina are shown in Fig. 1. The oviposition was significantly low at 15 to $25 \%$ salt concentrations $(\mathrm{p}<0.05)$. Only 5.0 and $0.12 \%$ oviposition occurred compared to that at the $5 \%$ dose. The egg deposition was gradually decreased with the increase of salt concentration (Fig. 1). These results suggest that the salt has an oviposition deterrent effect to L. cuprina. Similar results were found in other fly species where they oviposit

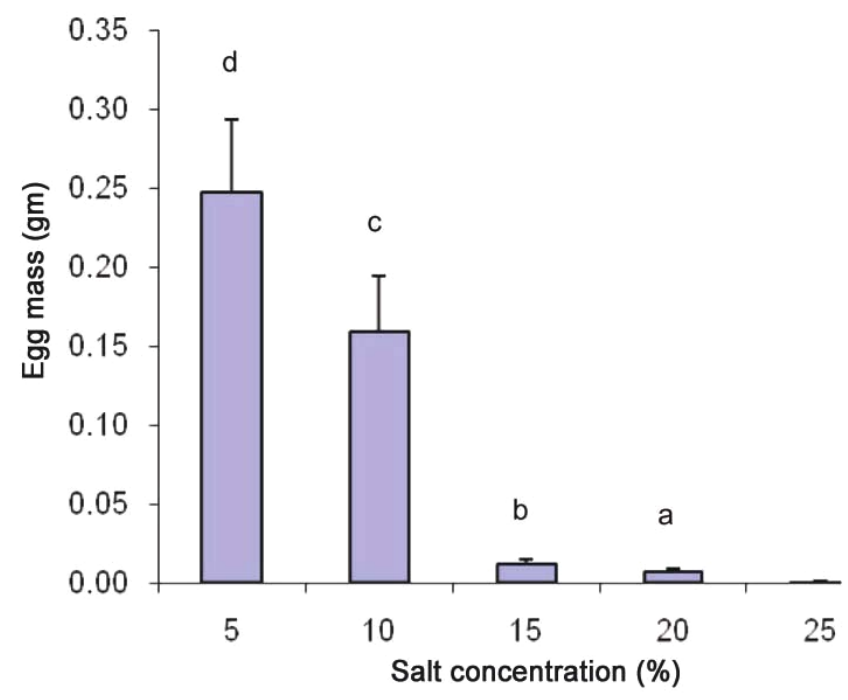

Fig. 1. Effect of $\mathrm{NaCl}$ concentration on oviposition by Lucilia cuprina. Mean represented by the different letters in the bar diagram are significantly different from each other at $5 \%$ level.

less with increase of salt concentrations ${ }^{(7,5)}$. In the present study L. cuprina oviposited only little amount of eggs $(0.003 \mathrm{~g})$ at $25 \%$ dose. Report showed that fish infesting flies possesses salt sensitive receptors which help them to detect salt and prevent them to lay 
eggs on salted medium(8-11). The growth and development of the larvae to adults were affected with increase of salt concentrations in the present study (Table 1). The increase of salt concentration in fishes above $5 \%$ significantly lengthens the larval duration $(p<0.05)$. The pupal duration, the larval and pupal weights were also increased significantly at higher concentrations of salts on the fish flesh. Similar reports are available in other reports $(5,7)$. In south Asian countries usually more than $6.4 \%$ salts are necessary to significantly reduce larval growth rate( ${ }^{(7)}$. In Kenya, Africa, larval growth and mortality trials indicated that 7 and $9 \%$ of salt concentrations are required to effectively stop larval growth of Lucilia species ${ }^{(5)}$.

Table 1. Effects of sodium chloride concentration on biological parameters of blowfly, Lucilia cupina.

\begin{tabular}{ccccccc}
\hline $\begin{array}{c}\text { Conc. of } \\
\text { salt }(\%)\end{array}$ & $\begin{array}{c}\text { Larval duration } \\
\text { (Days, mean } \pm \\
\text { SD) }\end{array}$ & $\begin{array}{c}\text { Pupal duration } \\
\text { (Days, mean } \pm \\
\text { SD) }\end{array}$ & $\begin{array}{c}\text { Mature larval } \\
\text { weight (Grams, } \\
\text { mean } \pm \text { SD) }\end{array}$ & $\begin{array}{c}\text { 3rd day old pupal } \\
\text { weight (Grams, } \\
\text { mean } \pm \text { SD) }\end{array}$ & $\begin{array}{c}\text { Pupation } \\
\text { rate } \\
(\%)\end{array}$ & $\begin{array}{c}\text { Adult } \\
\text { emergence rate } \\
(\text { mean } \pm \text { SD) }(\%)\end{array}$ \\
\hline 0 & $4.543 \pm 0.181$ & $4.833 \pm 0.753$ & $0.033 \pm 0.002$ & $0.026 \pm 0.001$ & 73.52 & $97.64 \pm 0.574$ \\
5 & $5.223 \pm 0.401 \mathrm{~ns}$ & $5.0 \pm 0.6325 \mathrm{~ns}$ & $0.0290 \pm 0.001 \mathrm{a}$ & $0.023 \pm 0.001 \mathrm{~ns}$ & $67.33 \mathrm{~ns}$ & $95.47 \pm 0.1 .78 \mathrm{~ns}$ \\
10 & $5.717 \pm 0.108 \mathrm{a}$ & $6.167 \pm 0.753 \mathrm{~ns}$ & $0.0245 \pm 0.0004 \mathrm{a}$ & $0.0154 \pm 0.002 \mathrm{a}$ & $52.13 \mathrm{a}$ & $91.86 \pm 1.577 \mathrm{a}$ \\
15 & $5.937 \pm 0.133 \mathrm{a}$ & $5.5 \pm 0.548 \mathrm{a}$ & $0.0149 \pm 0.001 \mathrm{a}$ & $0.012 \pm 0.0012 \mathrm{a}$ & $0.146 \mathrm{~b}$ & $5.54 \pm 2.955 \mathrm{~b}$ \\
20 & $00 \pm 00$ & $00 \pm 00$ & $00 \pm 00$ & $00 \pm 00$ & 00 & $00 \pm 00$ \\
\hline
\end{tabular}

$\mathrm{a}=(\mathrm{p}<0.05)$ and $\mathrm{b}=(\mathrm{p}<0.01)$ indicate significant difference from control. $\mathrm{ns}=$ no significant difference from control.

Table 2. Effects of sodium chloride concentrations on the longevity of adult Lucilia cuprina.

\begin{tabular}{ccccc}
\hline \multirow{2}{*}{$\begin{array}{c}\text { Concentration of } \\
\text { salt }(\%, w w b)\end{array}$} & \multicolumn{4}{c}{ Adult longevity (day) } \\
\cline { 2 - 5 } & \multicolumn{2}{c}{ Paired } \\
\cline { 2 - 5 } & Male & Female & Male & Fempaired \\
$($ Mean \pm SD) & $($ Mean \pm SD) & $($ Mean \pm SD) & $($ Mean \pm SD) \\
\hline 0 & $17.93 \pm 1.25$ & $19.7 \pm 0.914$ & $16.5 \pm 1.205$ & $18.9 \pm 0.919$ \\
5 & $13.5 \pm 1.178 \mathrm{~ns}$ & $14.1 \pm 1.524 \mathrm{~ns}$ & $13.8 \pm 0.763 \mathrm{~ns}$ & $14 \pm 1.330 \mathrm{~ns}$ \\
10 & $6.18 \pm 0.605 \mathrm{~b}$ & $7.7 \pm 0.395 \mathrm{~b}$ & $6.08 \pm 0.343 \mathrm{~b}$ & $7.08 \pm 0.531 \mathrm{a}$ \\
15 & 00 & 00 & 00 & 00 \\
20 & 00 & 00 & 00 & 00 \\
\hline
\end{tabular}

The mean pupation rate was decreased about 30 at $10 \%$ dose compared to that at the control but the rate goes down to 5 at $15 \%$ salt dose. The pupal weights were significantly decreased at higher salt concentration. The present findings suggest that the blowfly species of Bangladesh may have developed tolerance to relatively high salt concentration. The salt concentrations in excess of $15 \%$ are necessary to prevent significant infestation of fishes during sun drying. The Kenyan blowflies, L. cuprina, larvae reared on fish with 
$6.4 \%$ salt concentration were unable to develop into adults ${ }^{(5)}$. The differences of the findings could be due to the variation of the strains between Asian and African blowflies.

The present study revealed that salt concentration of $15 \%$ has lethal effect on egg, larva, pupa and adult. These results therefore, suggest that any losses of fish by fly infestation during sun-drying could be prevented or reduced by salting before drying.

\section{References}

1. Zumpt F 1965. Myiasis in Man and Animals in the Old World. Butter Worths, London, pp. 267.

2. Majumder MZR, ASM Saifullah and RN Khan 2008. Mass rearing and test release of radiosterilized flies in Sonadia Island and adjacent fish drying areas to control/ suppress blow fly Lucilia cuprina infesting sun-dried marine fish. In: Final Report of MOSICT research contact on capacity utilization program 2007-2008.

3. Davidson EW 1990. Microbial control of vector insects. In: New Direction in Biological Control. (Baker R and PE Dunn, Eds.). Liss, New York, pp. 126-135.

4. Robinson AS 2005. Genetic basis of sterile insect technique. In: Sterile Insect technique, Principles and practice in area wide integrated pest management. (Dyck VA, J Hendrichs and AS Robinson Eds.). Joint FAO/IAEA Programme Vienna, Austria, pp. 95-114.

5. Gitonga KN 2001. Use of salt to reduce post-harvest losses of cured fish due to blowfly (Lucilia and Chrysomya spp.) infestation in Kenya. Seventh FAO Expert Consultation on Fish Technology, Africa, pp. 57-60.

6. Duncan DB 1955. Multiple range and multiple F test. Biometrics 11: 1-42.

7. Esser JR 1990. The effects of salt concentration on oviposition and larval growth and mortality in the blowfly Chrysomya megacephala. Bull. Entomol. Res. 401: 180-184.

8. Gillary HL 1966. Stimulation of the salt receptor of the blowfly I. NaCl. The J. General Physiol. 50: $337-350$

9. Tompkins L, MJ Cardosa, FV White and TG Sanderst 1979. Isolation and analysis of chemosensory behavior mutants in Drosophila melanogaster. Proc. Natl. Acad. Sci. USA. 76(2): 884-887

10. Green AA 1967. The protection of dried sea fish in South Arabia from infestation by Drosophila frischii. J. Stored Prod. Res. 2: 331-335.

11. Proctor DL 1972. The protection of smoked-dried fresh-water fish from insect damage during storage in Zambia. J. Stored Prod. Res. 8(2): 139-149. 